\title{
Problematika Pengujian Peraturan Perundang-Undangan Di Mahkamah Agung (Kajian Terhadap Putusan Mahkamah Agung No. 65 P/HUM/2018)
}

\section{Suparto}

Fakultas Hukum Universitas Islam Riau, Pekanbaru, Indonesia E-mail:suparto@law.uir.ac.id

Dikirim: 24/10/2020

\begin{tabular}{l}
\hline Info Artikel \\
\hline Keywords: \\
Dualism; Testing; \\
Legislation; \\
Constitutional Court; \\
Supreme Court.
\end{tabular}

Kata Kunci:

Dualisme; Pengujian; PeraturanPerundangundangan; Mahkamah Konstitusi; Mahkamah Agung.
Direvisi: $15 / 03 / 2021$

Dipublikasi: 25/3/2021

\section{Abstract}

The Supreme Court (MA) decided that candidates for members of the Regional Representative Council (DPD) from political party administrators for the 2019 Election were still allowed, even though previously the Constitutional Court (MK) had banned it (Decision No. This conflict is due to differences in interpreting the timing of the implementation of the ongoing 2019 Election stage process. The Constitutional Court stated that the decision was enforced since the 2019 Election and this was not retroactive. Because it is still at the Provisional Candidate List (DCS) stage, so it is possible to change regulations. Meanwhile, the Supreme Court considers that the Constitutional Court's decision must be enforced after the 2019 Election or apply in the future (prospective), because the stages have been running, so that changes in requirements can be made The legal implication that occurs is that there is legal uncertainty for the General Election Commission (KPU) to follow which decision. To solve this problem can be used the doctrine of validity (enforceability of norms). The existence of a hierarchy of legal products being tested and a basis for testing certainly has a legal consequence of the existence of a hierarchy of norm validity in the decisions of the Supreme Court and the Constitutional Court. When there is a conflict between the Supreme Court decision and the Constitutional Court, the verdict with the basis and object of examination in the hierarchy of laws and regulations that is higher, namely the Constitutional Court decision, has a higher validity than the Supreme Court decision. So that problems like this do not exist anymore, testing of laws and regulations should only be carried out by one institution, namely the Constitutional Court.

\begin{tabular}{l}
\hline Abstrak \\
Mahkamah Agung (MA) memutuskan calon anggota Dewan Perwakilan \\
Daerah (DPD) dari pengurus partai politik untuk Pemilu tahun 2019 masih \\
diperbolehkan, padahal sebelumnya Mahkamah Konstitusi (MK) telah \\
melarangnya (Putusan No. 30/PUU-XVI/2018). Pertentangan ini \\
disebabkan adanya perbedaan dalam memaknai waktu penerapan \\
mengenai proses tahapan Pemilu tahun 2019 yang sedang berjalan. MK \\
menyatakan putusannya diberlakukan sejak Pemilu tahun 2019 dan hal ini \\
tidaklah berlaku surut (retroactive). Sebab masih pada tahapan Daftar \\
Calon Sementara (DCS), sehingga masih dimungkinkan terjadinya
\end{tabular}


DOI:

10.47268/sasi.v27i1.417 $\overline{\text { perubahan peraturan. Sedangkan MA menganggap putusan MK harus }}$ diberlakukan setelah Pemilu tahun 2019 atau berlaku kedepan (prospective), karena tahapan telah berjalan, sehingga masih dapat dilakukan perubahan persyaratan. Implikasi hukum yang terjadi adalah adanya ketidakpastian hukum bagi Komisi Pemilihan Umum (KPU) untuk mengikuti putusan yang mana. Untuk mengatasi permasalahan tersebut dapat digunakan doktrin validitas (keberlakuan norma). Adanya hierarki produk hukum yang diuji dan dasar pengujian tentunya memiliki akibat hukum adanya hierarki validitas norma dalam putusan MA dan MK. Ketika terjadi pertentangan antara putusan MA dengan MK, maka putusan dengan dasar dan objek pengujian dalam hierarki peraturan perundang-undangan yang lebih tinggi yakni putusan MK, memiliki validitas lebih tinggi dibandingkan dengan putusan MA. Agar permasalahan seperti ini tidak ada lagi, pengujian peraturan perundang-undangan sebaiknya hanya dilakukan oleh satu Lembaga saja yaitu di MK.

\section{A. PENDAHULUAN}

Indonesia merupakan sebuah Negara yang berlandaskan pada hukum. Oleh sebab itu penting adanya jaminan kesederajatan dimata hukum untuk semua rakyat Indonesia demi memenuhi prinsip dari Negara hukum itu sendiri. Perlakuan yang setara dihadapan hukum, kepastian hukum yang adil, serta jaminan, perlindungan dan pengakuan merupakan hak setiap orang yang harus Negara penuhi, hal tersebut termuat didalam konstitusi Indonesia yaitu Undang-Undang Dasar 1945 (UUD 1945). Indonesia sebagai negara hukum, maka untuk melaksanakan dan menegakkan hukum diperlukan lembaga peradilan yang berwenang di bidangnya, yang dalam perkembangannya di Indonesia lembaga peradilan tersebut pada puncaknya terbagi menjadi dua yaitu Mahkamah Agung dan Mahkamah Konstitusi. ${ }^{1}$

Upaya dalam mewujudkan kekuasaan kehakiman yang merdeka dalam bentuk peradilan satu atap dibawah Mahkamah Agung, akhirnya terwujud ketika tahun 2001 dilakukan perubahan terhadap Pasal 24 UUD 1945 yang kemudian disusul oleh lahirnya Undang-Undang Nomor 4 Tahun 2004 tentang Kekuasaan Kehakiman yang dicabut dan dinyatakan tidak berlaku oleh Undang-Undang Nomor 48 Tahun 2009 tentang Kekuasaan Kehakiman ${ }^{2}$, salah satu lembaga peradilan yang dapat dijadikan tempat pengaduan dalam masalah hukum adalah Mahkamah Agung (MA), sebagaimana termuat didalam Pasal 24 ayat (1) dan ayat (2) UUD NRI Tahun 1945 disamping Mahkamah Konstitusi (MK). Salah satu wewenang dan tugas yang dimiliki oleh MK adalah melakukan uji sebuah produk hukum yang dalam hirarkinya berada dibawah Undang-Undang.

Pengembalian Ketetapan MPR dalam hierarki peraturan perundang-undang dalam sistem hukum negara Indonesia tentunya membawa dampaknya tersendiri. Salah satunya adalah terhadap kewenangan Mahakamah Konstitusi dalam melakukan pengujian undang-undang ${ }^{3}$. Terkait tentang pengujian atau penilaian, pada umunya Negara di dunia menggunakan beberapa bentuk cara. Terdapat Negara yang memberikan penilain tersebut terhadap salah satu badan peradilannya yang biasa dikenal dengan hak uji yang dilakukan badan peradilan (judicial review). Atas pengujian yang dilakukan badan peradilan ini pun terdapat adanya cara atau

1 Satriawan, M. I., \& Mukhlis, M. (2018). Memurnikan Mahkamah Konstitusi. SASI, 24 (1), 47-58. https://doi.org/10.47268/sasi.v24i1.118, h. 51.

2 Suparto, S. (2020). Kontroversi Putusan Mahkamah Konstitusi Membatalkan Kewenangan Komisi Yudisial Melakukan Rekrutmen Terhadap Hakim. SASI, 26(2), 266-279. https://doi.org/10.47268/sasi.v26i2.252. h. 270.

3 Pratiwi, L.G. (2020). Kewenangan Uji Material (Judicial Review) terhadap Ketetapan Majelis Permusyawaratan Rakyat oleh Mahkamah Konstitusi. SASI, $26 \quad$ (4), 514-526. https://doi.org/10.47268/sasi.v26i4.268, h. 514.

62|S A S Vo1.27 No.1, Januari- Maret 2021 
praktek yang tidak sama. Contohnya seperti Amerika Serikat, demi melakukan uji peraturan perundang-undangan dan tindakan dari pemerintah memberikan kewenangan hak uji untuk semua badan peradilan umumnya (ordinary law courts). Pembahasan hak uji materiil (HUM) terhadap peraturan perundang-undangan pada MA tidak terlepas dari pembahasan mengenai check and balances, pemisahan kekuasaan dalam Negara, dan Negara hukum. Uji peraturan perundang-undangan yang berada dibawah undang-undang merupakan bagian dari judicial review, yaitu kewenangan dari MA dalam menguji atau menilai ada tidaknya pertentangan norma peraturan perundang-undangan yang berada dibawah undang-undang dengan peraturan perundang-undangan yang posisinya lebih tinggi. ${ }^{4}$

Uji materi terhadap Peraturan Komisi Pemilihan Umum (PKPU) No. 26 Tahun 2018 Tentang Perubahan Kedua atas PKPU No. 14 Tahun 2018 Tentang Pencalonan Perseorangan Peserta Pemilihan Umum Anggota Dewan Perwakilan Daerah (DPD) merupakan salah satu hak uji materiil yang telah dilakukan MA, pengujian ini dilaksanakan setelah adanya gugatan dari Oesman Sapta Odang, diakibatkan dicoretnya nama penggugat tersebut pada Daftar Calon Tetap (DCT) anggota DPD, hal ini buntut dari dikeluarkannya PKPU tersebut, yang mana pada Pasal 60A berisi aturan pelarangan terhadap pengurus dari partai politik untuk dapat menjadi anggota DPD sedangkan pemohon sendiri adalah ketua umum dari partai Hanura. Pemohon dalam hal ini Oesman Sapta Odang sebelumnya telah diloloskan KPU sebagai calon anggota DPD dan masuk dalam Daftar Calon Sementara (DCS) dengan merujuk pada PKPU No. 14 Tahun 2018 sebagai calon anggota DPD dapil Kalimantan Barat. Setelah namanya masuk sebagai DCS, MK membuat putusan hasil uji materi terhadap Pasal 182 UU No. 7 Tahun 2017 tentang Pemilu, judicial review tersebut mempersoalkan tentang ketentuan seseorang untuk dapat mencalonkan diri sebagai anggota DPD.

Pada 4 april tahun 2018 Muhammad Hafidz mengajukan permohonan uji materi ke MK, alasan uji materi karena pemohon merasa keberadaan dari lembaga DPD yang seharusnya merupakan sebagai representasi masyarakat daerah untuk mewakili daerahnya berpotensi dirugikan dengan adanya norma Pasal 182 huruf i UU No. 7 Tahun 2017 tentang pemilu, atas dasar itu pemohon merasa hak konstitusionalnya dirugikan, dikarenakan frasa "pekerjaan lain" yang termuat didalam pasal tersebut dalam pemaknaannya dirasa tertulis kurang jelas, dan tidak menjelaskan tentang apa sajakah yang dimaksud dari pekerjaan lain, apakah diantaranya salah satunya termasuk aktif sebagai pengurus partai politik, dengan pemaknaan yang tidak jelas tentang "frasa pekerjaan lain" tersebut menimbulkan kemungkinan bagi seorang pengurus parpol untuk dapat ikut serta mencalonkan diri dalam pemilihan anggota DPD, atas dasar tersebut pemohon merasa tidak mendapati hakikat dari keberadaan lembaga DPD yang memiliki kepastian hukum serta berkeadilan dalam wujud mewaliki daerah dimana seharusnya terbebas dari kepentingan-kepentingan partai politik.

Atas uji materi tersebut, MK mengabulkan permohonan yang diajukan pemohon, atas keputusan ini KPU melakukan pembaruan terhadap PKPU No.14 Tahun 2018 menjadi PKPU No. 26 Tahun 2018. KPU menambahkan frasa "Pengurus Partai Politik" sebagai pihak yang tidak diperbolehkan untuk rangkap jabatan sebagai anggota DPD. PKPU tersebut berdampak bagi calon anggota DPD yang sudah mendaftar, oleh sebab itu KPU memberi kesempatan bagi calon yang ada dalam DCS yang berasal dari partai politik untuk menyatakan mengundurkan diri dari kepengurusan partai politik yang didudukinya yakni tertuang pada Pasal 60A PKPU No. 26 Tahun 2018 agar tetap terdaftar sebagai calon anggota DPD. Hingga tanggal terakhir penetapan DCT, Oesman Sapta Odang tidak melaksanakan peraturan KPU yang baru, yang mengharuskan untuk mengundurkan diri dari kepengurusan partai politiknya, maka dari itu KPU memutuskan namanya tidak dimasukkan dalam surat keputusan (SK) tentang DCT

4 Sirajuddin. (2018). Desain Pengujian Peraturan Perundang-undangan Di Bawah Mahkamah Konstitusi, Jurnal Arena Hukum, 11 (2), 388-414. https://doi.org/10.21776/ub.arenahukum.2018.01002.9, h. 440. 
karena tidak memenuhi syarat pencalonan. Tidak terima dengan keputusan tersebut Oesman Sapta Odang melakukan upaya hukum yaitu dengan melaporkan KPU pada Badan Pengawas Pemilu (Bawaslu), menggugat SK yang dikeluarkan KPU tentang DCT anggota DPD ke Pengadilan Tata Usaha Negara (PTUN) dan menguji PKPU No. 26 Tahun 2018 ke MA.

Atas upaya hukum yang dilakukannya, Bawaslu menolak laporan yang diajukan Oesman Sapta Odang, namun gugatannya di PTUN dikabulkan, Hakim PTUN memutuskan memerintahkan KPU untuk mencabut surat keputusan tentang DCT anggota DPD yang telah dikeluarkannya yang tidak mencantumkan nama Oesman Sapta Odang, Majelis memerintahkan juga kepada KPU untuk menerbitkan ulang DCT baru dengan memuat nama Oesman Sapta Odang didalamnya. Selain itu MA juga mengabulkan Sebagian, pengujian PKPU oleh Oesman Sapta Odang yang tertuang dalam putusan MA No. 65P/HUM/2018. Dalam putusannya MA beralasan bahwa PKPU No. 26 Tahun 2018 bertentangan dengan peraturan yang posisinya lebih tinggi yaitu Pasal 5 huruf d dan Pasal 6 ayat (1) huruf I UU No. 12 Tahun 2011 tentang Pembentukan Peraturan Perundang-undangan dan menyatakan ketentuan pasal 60A PKPU No. 26 Tahun 2018 Tentang Perubahan Kedua atas PKPU No.14 Tahun 2018 tetap akan mempunyai kekuatan hukum mengikat dan berlaku umum apabila pemberlakuannya tidak surut kepada peserta pemilu anggota DPD tahun 2019 yang sudah melaksanakan tahap pendaftaran, program serta penjadwalan pelaksanaan Pemilu tahun 2019 menurut UU No. 7 Tahun 2017.

Putusan MA ternyata tidak sejalan dengan putusan MK yang telah terlebih dahulu memutuskan, hal ini menimbulkan ketidakpastian hukum khususnya bagi KPU terkait putusan manakah yang harus diikuti oleh KPU sebagai lembaga yang ditugaskan untuk menyelenggarakan Pemilihan Umum.

\section{B. PEMBAHASAN}

Salah satu kewenangan yang diberikan konstitusi kepada MA dalam melaksanakan kegiatan kekuasaan kehakiman, yakni melakukan pengujian peraturan perundang-undangan dibawah UU terhadap UU. Tujuan pemberian kewenangan hak uji terhadap peraturan perundang-undangan kepada MA dalam menjalankan fungsi kekuasaan kehakiman yaitu untuk mempertegas dan memperkokoh peran dan tugas MA agar mampu melaksanakan pengawasan kepada semua tindakan pemerintah maupun penguasa.

Salah satu hasil pengujian peraturan perundang-undangan di MA adalah Putusan No. 65 P/HUM/2018. Berdasarkan pertimbangan yang dikemukakan Hakim MA dalam putusan No. $65 \mathrm{P} / \mathrm{HUM} / 2018$ yang mengabulkan sebagian permohonan pemohon dimana anggota partai dapat maju dalam pemilihan anggota DPD serta tinjauan historis dari keberadaan lembaga DPD, penulis melihat ada hal yang ambigu dan terdapat konklusi yang seakan akan dipaksakan untuk membenarkan seorang anggota partai politik dapat maju dalam pemilihan anggota DPD. Dari pertimbangan tersebut ada dua isu hukum yang dijadikan pokok masalah yang ingin diselesaikan oleh MA dalam uji materiil tersebut yakni Pertama, KPU dalam hal ini yang memiliki kewenangan membentuk PKPU No. 26 Tahun 2018, dengan alasan menindak lanjuti Putusan MK No. 30/PUU-XVI/2018 untuk memberikan kepastian hukum disebabkan tahap Pemilu sudah berlangsung, karena DPR dan Presiden belum menindak lanjuti materi putusan tersebut. Kedua, apakah PKPU No. 26 Tahun 2018 tersebut dapat diterapkan pada tahapan Pemilu tahun 2019 kepada calon anggota DPD tahun 2019 yang mana tahapannya sudah berjalan sebelum PKPU tersebut dikeluarkan.

MA melakukan penafsiran hukum secara sistematis dalam mencari kewenangan KPU membuat PKPU terkait dalil yang dituntut oleh pihak pemohon. MA berpendapat bahwa terkait pembuatan PKPU, KPU memang mempunyai kewenangan yang bersifat atribusi yang diberikan oleh UU No. 7 Tahun 2017, sebagai lembaga negara yang memiliki kewenangan dalam penyelenggaraan Pemilu. KPU dalam membuat peraturan yang didasarkan dari putusan MK, MA melihat bahwa berdasarkan pada Pasal 10 ayat (2) UU No. 12 Tahun 2011, 
bahwasannya tindak lanjut terkait putusan MK dilakukan oleh Dewan Perwakilan Rakyat (DPR) bersama Presiden. Namun demikian terkait hal ini MA berpendapat bahwa hal ini tidak boleh dimaknai secara sempit, akan tetapi mesti dikaitkan dengan norma hukum yang lainnya, serta realitas pada saat putusan MK tersebut ditetapkan.

Atas tindakan KPU yang menindak lanjuti putusan dari MK yaitu No. 30/PUUXVI/2018 dengan membentuk PKPU No. 26 Tahun 2018 tanpa tindak lanjut dari DPR atau Presiden, MA beranggapan tidaklah bertentangan dengan kewenangan yang dimiliki oleh KPU. MA juga melihat pada konvensi ketatanegaraan yang dilakukan oleh kementerian dan juga lembaga Negara lain terkait dalam hal menindak lanjuti putusan yang dikeluarkan MK sejak diucapkan, meskipun belum ditindak lanjuti oleh DPR dan Presiden terlebih dahulu. Isu hukum berikutnya adalah apakah PKPU No. 26 Tahun 2018 bisa diberlakukan kepada calon anggota DPD pada tahap Pemilu tahun 2019 yang telah lebih dahulu dilaksanakan sebelum peraturan tersebut dikeluarkan, dalam hal ini MA berpandangan peraturan tersebut tidak bisa diberlakukan pada calon anggota DPD pada Pemilu 2019 disebabkan peraturan tersebut tidak dapat diberlakukan surut (retroactive).

Menurut penulis permasalahan yang menyebabkan terjadinya perbedaan antara kedua putusan ini adalah dalam memaknai dan mengartikan waktu proses tahapan, program, dan penjadwalan penyelenggaraan pemilu yang sedang berjalan yang akhirnya menimbulkan perbedaan tafsiran putusan yang berkaitan tentang asas retroactive. MK menyebutkan putusannya berlaku pada Pemilu tahun 2019 artinya tidak berlaku surut (retroactive), disebabkan tahap Pemilu kala itu saat putusan MK dikeluarkan belum masuk pada tahap Daftar Calon Tetap (DCT), sehingga atas dasar tersebut masih memungkinkan adanya perubahan peraturan yang berdampak terhadap calon anggota DPD pada Pemilu tahun 2019. Sedangkan putusan dari MA dan PTUN menganggap putusan MK harus diberlakukan setelah Pemilu tahun 2019, sebab tahapan proses pencalonan dengan persyaratan yang ada telah dilaksanakan sebelum adanya DCT, sehingga tidak mungkin lagi untuk dilakukan perubahan terhadap persyaratan pencalonan. ${ }^{5}$

Pertimbangan hakim MA yang menyatakan bahwa ketentuan Pasal 60A PKPU No. 26 Tahun 2018 bertentangan dengan ketentuan Pasal 5 huruf d dan Pasal 6 ayat (1) huruf i UU No. 12 Tahun 2011 dikarenakan pasal 60A PKPU No. 26 Tahun 2018 tersebut diberlakukan surut adalah kurang tepat. Ada kekeliruan dari hakim MA dalam menafsirkan bahwa peraturan itu berlaku surut, sebab pernyataan tentang calon anggota DPD Pemilu tahun 2019 terkena dampak dari putusan pelarangan pengurus partai mencalonkan diri sebagai calon anggota DPD tertuang dalam putusan MK No. 30/PUU-XVI/2018 pada point putusan [3.17] yang menyatakan : "Bahwa untuk Pemilu tahun 2019, karena proses pendaftaran calon anggota DPD telah dimulai, dalam hal terdapat bakal calon anggota DPD yang kebetulan merupakan pengurus partai politik terkena dampak oleh putusan ini, KPU dapat memberikan kesempatan kepada yang bersangkutan untuk tetap sebagai calon anggota DPD sepanjang telah menyatakan mengundurkan diri dari kepengurusan Partai Politik yang dibuktikan dengan pernyataan tertulis yang bernilai hukum perihal pengunduran diri dimaksud. Dengan demikian untuk selanjutnya, anggota DPD sejak Pemilu 2019 dan Pemilu-Pemilu setelahnya yang menjadi pengurus partai politik adalah bertentangan dengan UUD 1945."

Atas dasar itu dapat dijelaskan bahwa pelarangan tersebut diberlakukan bagi calon anggota DPD pada Pemilu tahun 2019 yang telah mendaftar untuk nantinya tetap terdaftar calon anggota Pemilu, sebab saat putusan itu dikeluarkan status calon anggota DPD untuk Pemilu tahun 2019 masih dalam status daftar calon sementara (DCS), dengan kata lain putusan tersebut berlaku bagi calon anggota DPD yang ingin selanjutnya terdaftar dalam DCT, bukan pelarangan

5 Faiz, P. M., Winata, R. M. (2019). Respon Konstitusional Larangan Calon Anggota Dewan Perwakilan Daerah Sebagai Pengurus Partai Politik. Jurnal Konstitusi, 16 (3), 532-558. https://doi.org/10.31078/jk1635, h. 540.

$$
\text { 65|SASI Vo1. } 27 \text { No.1, Januari-Maret } 2021
$$


atau menggugurkan calon yang telah terdaftar sebagai DCS. Sebab tahapan pendaftaran pemilu baru berhenti ketika penetapan DCT. Hakim MK juga telah menyatakan apabila terdapat calon anggota DPD yang berasal dari pengurus partai politik terkena dampak oleh putusan ini dan bila ingin tetap terdaftar sebagai calon anggota DPD maka harus mengundurkan diri dari pengurus partai politik, dengan begitu jelas bahwa putusan ini ditujukan bagi calon anggota DPD untuk tahap pendaftaran selanjutnya. Sejalan dengan hal tersebut KPU mencoret nama Oesman Sapta Odang pada DCT, bukan pada DCS anggota DPD 2019. Dengan demikian pernyataan pemberlakuan surut sebuah peraturan sebagaimana dinyatakan oleh hakim MA adalah tidak tepat.

Dalam putusannya MK menyatakan pelarangan bagi pengurus partai politik untuk maju mencalonkan diri sebagai calon anggota DPD tidak hanya berlaku untuk pemilu kedepan tetapi juga bagi calon anggota DPD Pemilu tahun 2019. Atas dasar ini KPU membuat peraturan baru tentang calon anggota DPD. Ini tentu tidak sesuai dengan alasan MA yang menyatakan peraturan KPU tersebut berlaku surut, sebab peraturan itu merupakan perintah langsung dari putusan MK bukan tafsiran yang dilakukan oleh KPU, tentu hal ini tidak bisa dianggap bertentangan dengan ketentuan Pasal 5 huruf d dan Pasal 6 ayat (1) huruf i UU No. 12 Tahun 2011. Hal ini memperlihatkan bahwa MA tidak mempertimbangkan putusan dari MK tersebut dan malah seakan akan membantah putusan tersebut dan menyatakan hal itu tidak dapat dilaksanakan karena suatu peraturan tidak bisa diberlakukan surut, hal ini tentu menimbulkan konflik kompetensi antara MA dengan MK.

Adanya ketentuan bahwa daftar calon sementara (DCS) anggota DPD 2019 terkena dampak dari putusan larangan pengurus partai mencalonkan diri sebagai calon anggota DPD terdapat dalam putusan MK No. 30/PUU-XVI/2018 dimana putusan MK memiliki kekuatan hukum mengikat sederajat dengan undang-undang, sebagaimana ditegaskan dalam Pasal 47 UU No. 24 Tahun 2003 Tentang MK yang menyatakan "putusan Mahkamah Konstitusi memperoleh kekuatan hukum mengikat sejak selesai diucapkan dalam sidang pleno terbuka untuk umum". Atas dasar pertimbangan hukum, dan analisis terhadap karakteristik setiap putusan, dapat ditarik kesimpulan bahwa adanya pertentangan hukum yang terjadi antara Putusan MA dan MK, maupun PTUN merupakan perbedaan pendapat mengenai waktu pemberlakuan larangan calon anggota DPD yang berasal dari pengurus partai politik. MK menyatakan berlaku sejak Pemilu tahun 2019, sedangkan MA menyatakan mulai berlaku setelah Pemilu tahun 2019.

Problematika yang muncul dalam pelaksanaan putusan MK No. 30/PUU- XVI/2018 adalah perihal berlakunya putusan tersebut. MA yang mengabulkan sebagian permohonan uji materi terhadap PKPU No. 26 Tahun 2018 berpendapat bahwa putusan MK tidak boleh berlaku surut terhadap bakal calon anggota DPD yang telah melalui tahapan verifikasi. Persinggungan kewenangan antara MA dan MK dapat menimbulkan ketidakpastian hukum. Namun apabila melihat dari sifat putusan MK yang bersifat final dan mengikat maka putusan MK No. 30/PUU-XVI/2018 harus langsung dilaksanakan sama halnya dengan undang-undang. Artinya putusan tersebut harus segera dilaksanakan setelah diucapkan dalam sidang terbuka dan berlaku asas erga omnes setelah dimuat dalam berita negara. Sedangkan penyerahan pengunduran diri tertulis dari pengurus partai politik merupakan suatu kebijaksanaan yang diberikan karena proses pendaftaran bakal calon anggota DPD telah berlangsung. ${ }^{6}$

Implikasi hukum yang terjadi akibat putusan yang saling bertentangan antara putusan MA dengan putusan $\mathrm{MK}$, penulis merasa perlu menjabarkan permasalahan ini terlebih dahulu menggunakan analisis dari susunan peraturan perundang-undangan, serta sifat final dari sebuah putusan. Merujuk pada UUD 1945 yang menjadi dasar hukum terbentuknya kedua lembaga kekuasaan kehakiman ini, didalam UUD 1945 tidak dijelaskan secara tegas mengenai

${ }^{6}$ Hardani, A., Whardani, L. T. A. L. (2019). Implementasi Putusan Mahkamah Konstitusi Nomor: 30/PUUXVI/2018 Menurut Sistem Hukum Di Indonesia. Jurnal Pembangunan Hukum Indonesia, 1 (2), 182-193, https://doi.org/10.14710/jphi.v1i2.182-193, h. 189.

$$
\text { 66|S A S I Vol. } 27 \text { No.1, Januari - Maret } 2021
$$


kewenangan yang dimiliki MA tentang kewenangan uji materiil peraturan perundang-undangan dibawah undang-undang terhadap undang-undang, pada pasal 24A UUD 1945 hanya menjelaskan salah satu kewenangan dari MA adalah "menguji peraturan perundang-undangan di bawah undang-undang terhadap undang-undang" tetap tidak ada menjelaskan uji materiil yang dilakukan Mahkamah Agung putusannya bersifat final.

UU No. 3 Tahun 2009 Tentang Mahkamah Agung juga tidak mengatur soal finalitas putusan dari MA, hal tersebut juga tidak terdapat pada UU No. 14 Tahun 1985 dan UU No. 5 Tahun 2004 semuanya tidak ada yang mengatur soal putusan MA sifatnya final. Ketentuan yang mengatur final dari putusan MA terdapat pada Pasal 9 Peraturan MA No. 1 Tahun 2011 tentang Hak Uji Materil yang menyatakan, "Terhadap putusan mengenai permohonan keberatan tidak dapat diajukan Peninjauan Kembali". Atas dasar norma peraturan ini, maka putusan uji materi oleh MA juga bersifat final dan mengikat umum (erga omnes) kepada seluruh lembaga negara dan warga negara. Sedangkan sifat final putusan yang dimiliki oleh MK terhadap uji materiil UU terhadap UUD 1945 diatur pada Pasal 24C ayat (1) yang mengatur "bahwa salah satu kewenangan yang dimiliki MK yaitu mengadili pada tingkat pertama dan terakhir yang putusannya bersifat final dalam menguji undang-undang terhadap Undang-Undang Dasar". Naskah Komprehensif Perubahan UUD 1945 menjelaskan: "MK merupakan badan peradilan tingkat pertama dan terakhir atau badan peradilan satu-satunya yang putusannya bersifat final dan mengikat untuk melaksanakan kewenangannya, MK tidak mengenal adanya mekanisme banding atau kasasi." sehingga tidak dimungkinkan adanya lembaga negara manapun yang berwenang menguji kembali putusan yang dikeluarkan MK.

Pasal 10 UU No. 24 Tahun 2003 menegaskan soal finalitas dari putusan MK, dalam pasal tersebut menyebutkan "putusan MK langsung memperoleh kekuatan hukum tetap sejak diucapkan dan tidak ada upaya hukum lain yang dapat ditempuh". Atas hal tersebut maka telah jelas putusan MK adalah final dan mengikat umum (erga omnes) terhadap seluruh lembaga negara dan warga negara sejak dibacakan dan bersifat ke depan (prospektive). ${ }^{7}$ Dengan demikian dapat diartikan, bahwa putusan MA maupun putusan MK mempunyai kekuatan hukum mengikat kepada KPU, sehingga KPU harus mematuhi dari kedua putusan tersebut. Namun, dengan adanya pertentangan dalam putusan terkait waktu pemberlakuan norma larangan calon anggota DPD sebagai pengurus partai politik mengharuskan KPU untuk memilih, putusan lembaga peradilan mana yang harus dilaksanakan dalam menentukan persyaratan calon anggota DPD Pemilu tahun 2019. ${ }^{8}$

Putusan MA No. 65P/HUM/2018 menimbulkan polemik khususnya bagi KPU, akibat putusan antara MA dan MK yang saling kontradiksi, hal ini mengakibatkan terjadinya ketidakpastian hukum yang membuat KPU harus merujuk pada putusan yang mana, akibat ada dua putusan yang eksis tentang kasus yang sama tetapi saling bertentangan. Sikap MA yang berpandangan bahwa PKPU No. 26 Tahun 2018 yang dibentuk atas dasar putusan MK tidak bisa diberlakukan surut bagi peserta Pemilu calon anggota DPD tahun 2019 merupakan tindakan yang keliru. Putusan MK yang melarang pengurus parpol untuk menjadi calon anggota DPD adalah konstitusional dan sederajat dengan UU, karena batu uji dari uji materi di MA adalah UU oleh karena itu putusan MK adalah bagian yang harusnya wajib diperhatikan dan menjadi pertimbangan oleh MA.

Dengan adanya situasi yang demikian tindakan yang harus dilakukan ketika ada pertentangan antara putusan MK dengan putus MA, adalah mendasarkan pada analisis terhadap doktrin validitas atau keberlakuan norma, sehingga ditemukan rasionalisasi putusan mana yang harus dilaksanakan oleh KPU. Validitas atau keberlakuan norma adalah doktrin yang

7 Mulyanto, A. (2013). Problematika Pengujian Peraturan Perundang-undangan (Judicial Review) di Mahkamah Agung dan Mahkamah Konstitusi, Jurnal Yustisia, 2 (1), 57-65. https://doi.org/10.20961/yustisia.v2i1.11070, h. 62.

${ }^{8}$ Putra, A. (2018). Dualisme Pengujian Peraturan Perundang-undangan, Jurnal Legislasi Indonesia, 15 (2), 69-79, https://e-jurnal.peraturan.go.id/index.php/jli/article/view/172, h. 76.

$$
\text { 67|SASI Vol. } 27 \mathrm{No.1,} \text { Januari- Maret } 2021
$$


menjelaskan mengenai kekuatan mengikat (binding force) suatu norma sehingga harus dilaksanakan. ${ }^{9}$

Validitas dari suatu norma merupakan doktrin yang menjelaskan tentang bagaimana dan apa syarat dari suatu norma hukum untuk menjadi legitimate atau sah berlaku, dan kemudian dapat diberlakukan kepada masyarakat. Dengan analisis menggunakan doktrin validitas norma dan hierarki norma yang sudah diurai diatas dapat dijelaskan bahwa sebuah peraturan itu sejatinya berbentuk hierarki dan peraturan yang tingkatannya lebih tinggi harus menjadi sumber serta dasar untuk pembentukan peraturan yang tingkatannya lebih rendah dan tidak boleh bertentangan. Atas dasar tersebut dapat disimpulkan bahwasannya peraturan perundangundangan yang lebih tinggi harus menjadi dasar dalam menentukan validitas dari peraturan perundang-undangan yang lebih rendah. ${ }^{10}$

Adanya doktrin tersebut dapat digunakan sebagai acuan oleh KPU dalam mengambil keputusan, tindakan apa yang harus dilakukan oleh KPU terhadap adanya pertentangan antara putusan MA dengan putusan MK maupun dengan putusan PTUN. Dengan adanya tingkatan atau hierarki dari sebuah produk hukum yang diuji dan dasar pengujiannya, tentunya memiliki akibat hukum adanya hierarki validitas norma dalam putusan MA dan MK. Apabila terjadi pertentangan antara putusan MA dengan putusan MK, maka putusan dengan dasar pengujian dan objek pengujian dalam hierarki pengujian peraturan perundang-undangan yang lebih tinggi dalam hal ini putusan MK memiliki validitas atau keberlakuan hukum lebih tinggi dibandingkan dengan putusan MA. ${ }^{11}$

Dengan demikian tindakan KPU yang akhirnya berpegangan pada putusan MK dan mengabaikan putusan MA meski tetap menghormati putusan tersebut, dengan tetap memberlakukan pelarangan terhadap calon anggota DPD yang memiliki jabatan pengurus partai politik sejak Pemilu tahun 2019 dan menolak memasukan ke dalam DCT Pemilu tahun 2019 merupakan tindakan yang sudah tepat, karena kedudukan putusan MK yang lebih tinggi dengan batu uji terhadap UUD 1945 yang merupakan hukum tertinggi di Indonesia. ${ }^{12}$ Terjadinya putusan yang saling bertentangan seperti ini akan sangat mungkin terjadi kembali dari kedua lembaga peradilan ini, hal ini bukanlah pertama kalinya terjadi. Setelah terbitnya putusan MA yang inkonsisten dengan putusan MK dalam kasus yang sama, perlu dipikirkan format baru terkait kewenangan dalam menguji peraturan perundang-undangan dari dua pemegang kekuasaan kehakiman tersebut. Sebab jika tidak, kasus serupa akan terus terjadi dan menimbulkan ketidakpastian hukum dan polemik yang merupakan risiko atas adanya dua jalur pengujian peraturan perundang-undangan dalam sistem hukum Indonesia. ${ }^{13}$

Menurut penulis dengan adanya dua badan peradilan yang memiliki kewenangan yang sama dalam melakukan pengujian peraturan perundang-undangan (walaupun objeknya berbeda) di Indonesia akan selalu memiliki peluang untuk terjadinya putusan yang saling bertentangan seperti kasus ini. Pelaksanaan pengujian peraturan perundang-undangan, dengan hanya membedakan objek dan institusi yang berbeda tetapi dalam kekuasaan negara yang sama (kekuasaan kehakiman), akan menimbulkan masalah. Pemisahan kewenangan pengujian antara MA dan MK sebagaimana yang berlaku saat ini tidaklah ideal karena dapat menimbulkan permasalahan. Sebab akan selalu ada kaitan antara UU dan peraturan dibawahnya, oleh sebab

9 Sudarsono. (2017). Pengujian Peraturan Perundang-undangan Di Bawah Undang-Undang Oleh Mahkamah Agung, Jurnal Mimbar Yustitia, $1 \quad$ (2), 2017, $147-169$, http://ejurnal.unisda.ac.id/index.php/mimbar/article/view/832, h. 15

10 Asshiddiqie, J., Safa'at, M. A. (2006). Teori Hans Kelsen Tentang Hukum, Jakarta : Sekretariat Jenderal dan Kepaniteraan Mahkamah Konstitusi RI, h. 87

11 Helmi, M. I. (2019). Penyelesaian Satu Atap Perkara Judicial Review Di Mahkamah Konstitusi, Salam: Jurnal Sosial dan Budaya Sar-i, 6 (1), 97-112. https://doi.org/10.15408/sjsbs.v6i1.10551, h. 110.

12 Alfath, T. P. (2019). Eksekutabilitas Putusan Mahkamah Agung Terhadap Pencalonan Anggota Dewan Perwakilan Daerah. Jurnal Yudisial, 12 (3), 287-303. http://dx.doi.org/10.29123/jy.v12i3.357, h. 301.

13 Abustan. (2017). Relasi Lembaga Negara Dalam Perspektif Undang-Undang Dasar Negara Republik Indonesia 1945, Unifikasi: Jurnal Ilmu Hukum, 4 (2), 55-63, https://doi.org/10.25134/unifikasi.v4i2.693, h.58 
itu tidaklah ideal apabila ada dua institusi peradilan yang melakukan pengujian peraturan perundang-undangan.

Selain menyatukan pengujian peraturan perundang-undangan dalam satu atap, penulis $j$ merasa perlu untuk memperbaharui kewenangan dari kedua lembaga ini sesuai konsep aslinya, yaitu MA dengan konsep court of justice hanya fokus pada bagian memberikan keadilan, dan MK dengan konsep court of law hanya fokus pada penegakan segala peraturan perundangundangan terhadap UUD 1945 dari penyimpangan, yang mana kedua tugas tersebut saling dimiliki oleh MA maupun MK saat ini, contohnya sebagai pengadilan untuk memberikan keadilan MA juga mempunyai kewenangan untuk melakukan pengujian peraturan perundangundangan, tentu ini tidak sesuai dengan konsepnya sebagai court of justice, dan MK sebagai court of law dalam salah satu wewenangnya juga mengurusi bidang keadilan yaitu memberikan putusan terhadap pendapat DPR untuk memberhentikan Presiden atau Wakil Presiden.

Mahfud MD juga berpendapat seharusnya mengenai kompetensi dua lembaga kekuasaan kehakiman diatur MK menangani konflik peraturan perundang-undangan guna menjamin konsistensi semua peraturan perundang-undangan sedangkan MA menangani konflik antar orang dan/atau lembaga. ${ }^{14}$ Pandangan serupa juga dipaparkan oleh Jimly Asshiddiqie, menurutnya idealnya lembaga negara penguji peraturan perundang-undangan disatukan pada satu lembaga saja. ${ }^{15}$ Penyatuan dalam satu atap pengujian peraturan perundang-undangan ini, memerlukan amandemen atau terhadap UUD 1945. Perubahan dapat dilakukan dengan menambah kewenangan MK dalam Pasal 24C UUD 1945, yaitu menguji semua peraturan perundang undanganyang di Indonesia.. ${ }^{16}$

Terkait sanggahan hakim MA yang menyatakan bahwa PKPU No. 26 Tahun 2018 Pasal 60A yang merupakan peraturan yang dikeluarkan atas dasar putusan MK merupakan peraturan yang diberlakukan surut atau retroaktif, meski dalam kasus tersebut telah penulis paparkan tidak ada yang diberlakukan surut, disini perlu ada pengecualian terkait pelaksanaan peraturan berlaku surut agar diberikan kepada MK demi menjaga konstitusi, saat ini putusan dari MK mengharuskan bersifat prospektif atau berlaku kedepan, tidak berlaku surut. Penulis berpendapat hal tersebut perlu diperbarui sebab MK sebagai lembaga yang memperjuangkan dan menjaga konstitusi dapat mengalami hambatan dalam melaksanakan tugasnya apabila ada sebuah peraturan yang menyalahi ketetapan konstitusi dan peristiwa hukumnya telah terjadi, seperti halnya pernah terjadi dalam putusan MK sebelumnya.

Ketua MK saat itu yaitu Mahfud MD mengakui putusannya berlaku surut, namun beliau menyatakan bahwa apabila hanya bersifat prospektif, MK khawatir tujuan perlindungan konstitusi akan gagal tercapai. Sejalan dengan hal tersebut penulis merasa perlu diberikan keleluasaan bagi MK dalam memberikan suatu putusan terkait uji materi suatu peraturan perundang-undangan untuk bersifat surut kebelakang sepanjang memang hal itu diperlukan dan sesuai dengan spirit konstitusi, karena bagaimanapun juga apabila ada peraturan yang dianggap MK bertentangan dengan konstitusi harus dihentikan dan diperbarui sesuai nilai-nilai yang terkandung dalam konstitusi meski harus berlaku surut. ${ }^{17}$ Segala peraturan disuatu Negara haruslah sesuai dengan apa yang ada dalam konstitusinya, apabila menyalahi konstitusi tentu sebenarnya peraturan tersebut telah salah sejak dikeluarkannya. Apabila putusan MK selalu prospektif atau berlaku kedepan ada peluang terjadinya ketidakpastian terhadap suatu hukum saat dijalankan, disatu sisi undang-undang mengatur peristiwa hukum tersebut namun disisi lain

14 MD, Moh Mahfud. (2015). Titik Singgung Wewenang antara MA dan MK, Jurnal Hukum dan Peradilan, 4 (1), 1-16. http://dx.doi.org/10.25216/jhp.4.1.2015.1-16, h. 14

15 Asshiddiqie, J. (2010). Perihal Undang-Undang, Jakarta : Rajawali Pers, h. 41

16 Sirajuddin., Ramadhan, F. (2019). Dualisme Pengujian Yang Berujung Tirani Keterwakilan : Kajian atas Putusan Mahkamah Agung No. 65/P/HUM/2018 dan Putusan Mahkamah Konstitusi No. 30/PUU-XVI/2018. Jurrnal Hukum Kenegaraan, 2 (1), 1-20, 16-17.

17 M D, Moh Mahfud. Op. Cit. h.15

$$
\text { 69|S A S Vo1. } 27 \text { No.1, Januari-Maret } 2021
$$


konstitusi menyatakan sebaliknya. ${ }^{18}$ Penulis berpendapat pengecualian ini diperlukan demi penegakan konstitusi, pengecualian dari asas retroaktif saat ini diberlakukan pada pelanggaran hak asasi manusia. Penerapan serupa pada putusan MK bukanlah hal yang melanggar norma hukum yang ada, karena sejatinya konstitusi merupakan hukum tertinggi disuatu Negara, apabila terjadi pertentangan norma hukum pada isi dari suatu peraturan, sudah seharusnya ditindak lanjuti dengan segera meski harus berlaku surut.

Rekonstruksi ketatanegaraan memang sulit dilakukan sekaligus tetapi diperlukan pentahapan. Tetapi amandemen parsial yang diberlakukan secara instan justru akan mengacaukan hukum tata negara. Jika hal ini berlanjut maka (perubahan) konstitusi hanya mencerminkan pandangan dan kepentingan para perumusnya dalam kontek transisi politik dewasa ini, dan banyak diantara perumus tak tercerahkan dibawah sosialisasi politik Orde Baru, kepentingan itu bersifat parochial, sesaat, dan menjengkelkan publik. Perubahan-perubahan konstitusi oleh MPR harus mengalami amandemen. ${ }^{19}$

\section{P E N U T U P}

MA memutuskan calon anggota DPD dari pengurus partai politik untuk Pemilu tahun 2019 masih diperbolehkan, padahal sebelumnya MK telah memutuskan melarang anggota DPD dari pengurus partai politik ikut Pemilu sejak tahun 2019. Adanya putusan yang saling bertentangan tersebut terjadi dikarenakan adanya perbedaan dalam memaknai waktu penerapan dalam Pemilu tahun 2019 yang sedang berjalan. MK menyatakan berlaku sejak Pemilu tahun 2019 dan ini tidaklah berlaku surut (retroactive) karena tahapan Pemilu pada saat MK memutuskan belum masuk dalam tahapan Daftar Calon Tetap (DCT) masih dalam tahapan Daftar Calon Sementara (DCS), sehingga masih memungkinkan untuk dilakukan perubahan peraturan yang berdampak kepada calon anggota DPD. Sedangkan MA menganggap putusan MK harus diberlakukan setelah Pemilu tahun 2019 atau harus berlaku kedepan (prospective), karena tahapan proses pencalonan telah berjalan sebelum adanya DCT, sehingga tidak dimungkinkan untuk dilakukan adanya perubahan persyaratan pencalonan. Implikasi hukum yang terjadi akibat putusan MA yang bertentangan dengan putusan MK, menimbulkan ketidakpastian hukum khususnya bagi KPU untuk mengikuti putusan yang mana, dengan menggunakan doktrin validitas atau keberlakukan norma, maka ketika terjadi pertentangan antara putusan MA dengan MK, maka putusan dengan dasar pengujian dan objek pengujian dalam hierarki peraturan perundang-undangan yang lebih tinggi yakni MK memiliki validitas atau keberlakuan hukum lebih tinggi. Sehingga KPU harus berpedoman pada putusan MK.

Pemutusan perkara pengujian peraturan perundang-undangan Hakim MA harus menjadikan putusan MK sebagai bahan pertimbangan agar tidak timbul putusan yang bertentangan yang dapat menimbulkan ketidakpastian hukum. Perlunya penyatuan lembaga penguji peraturan perundang-undangan dalam satu atap dengan mengembalikan lembaga kekuasaan kehakiman ini sesuai format aslinya yaitu MA dengan konsep court of justice hanya fokus pada penegakan keadilan, dan MK dengan kosep court of law hanya fokus pada penegakan segala peraturan perundang-undangan terhadap UUD 1945 dari penyimpangan, dengan kata lain pengujian peraturan perundang-undangan hanya dilakukan oleh MK saja.

18 Al-Fatih, S. (2018). Model Pengujian Peraturan Perundang-undangan Satu Atap Melalui Mahkamah Konstitusi, Legality: Jurnal Ilmiah Hukum, $25 \quad$ (2), https://ejournal.umm.ac.id/index.php/legality/article/view/6005, h. 256

19 Yunaldi, W. (2018). Judicial Review Satu Atap Peraturan Perundang-undangan Di Bawah Kewenangan Mahkamah Konstitusi. Pagaruyuang Law Journal, 1 (2), 198-219, https://jurnal.umsb.ac.id/index.php/pagaruyuang/article/view/565, h. 201 


\section{Jurnal}

[1] Abustan. (2017). Relasi Lembaga Negara Dalam Perspektif Undang-Undang Dasar Negara Republik Indonesia 1945, Unifikasi: Jurnal Ilmu Hukum, 4 (2), 55-63, https://doi.org/10.25134/unifikasi.v4i2.693.

[2] Al-Fatih, S. (2018). Model Pengujian Peraturan Perundang-undangan Satu Atap Melalui Mahkamah Konstitusi, Legality: Jurnal Ilmiah Hukum, 25 (2), 247-260, https://ejournal.umm.ac.id/index.php/legality/article/view/6005.

[3] Alfath, T. P. (2019). Eksekutabilitas Putusan Mahkamah Agung Terhadap Pencalonan Anggota Dewan Perwakilan Daerah. Jurnal Yudisial, 12 (3), 287-303. http://dx.doi.org/10.29123/jy.v12i3.357.

[4] Faiz, P. M., Winata, R. M. (2019). Respon Konstitusional Larangan Calon Anggota Dewan Perwakilan Daerah Sebagai Pengurus Partai Politik. Jurnal Konstitusi, 16 (3), 532-558. https://doi.org/10.31078/jk1635.

[5] Hardani, A., Whardani, L. T. A. L. (2019). Implementasi Putusan Mahkamah Konstitusi Nomor: 30/PUU-XVI/2018 Menurut Sistem Hukum Di Indonesia. Jurnal Pembangunan Hukum Indonesia, 1 (2), 182-193, https://doi.org/10.14710/jphi.v1i2.182-193.

[6] Helmi, M. I. (2019). Penyelesaian Satu Atap Perkara Judicial Review Di Mahkamah Konstitusi, Salam: Jurnal Sosial dan Budaya Sar-i, 6 (1), 97-112. https://doi.org/10.15408/sjsbs.v6il.10551.

[7] Mulyanto, A. (2013). Problematika Pengujian Peraturan Perundang-undangan (Judicial Review) di Mahkamah Agung dan Mahkamah Konstitusi, Jurnal Yustisia, 2 (1), 57-65. https://doi.org/10.20961/yustisia.v2i1.11070.

[8] MD, Moh Mahfud. (2015). Titik Singgung Wewenang antara MA dan MK, Jurnal Hukum dan Peradilan, 4 (1), 1-16. http://dx.doi.org/10.25216/jhp.4.1.2015.1-16.

[9] Putra, A. (2018). Dualisme Pengujian Peraturan Perundang-undangan, Jurnal Legislasi Indonesia, 15 (2), 69-79, https://e-jurnal.peraturan.go.id/index.php/jli/article/view/172.

[10] Pratiwi, L.G. (2020). Kewenangan Uji Material (Judicial Review) terhadap Ketetapan Majelis Permusyawaratan Rakyat oleh Mahkamah Konstitusi. SASI, 26 (4), 514-526. https://doi.org/10.47268/sasi.v26i4.268.

[11] Sudarsono. (2017). Pengujian Peraturan Perundang-undangan Di Bawah Undang-Undang Oleh Mahkamah Agung, Jurnal Mimbar Yustitia, 1 (2), 2017, 147-169, http://ejurnal.unisda.ac.id/index.php/mimbar/article/view/832.

[12] Satriawan, M. I., \& Mukhlis, M. (2018). Memurnikan Mahkamah Konstitusi. SASI, 24 (1), 47-58. https://doi.org/10.47268/sasi.v24i1.118.

[13] Sirajuddin. (2018). Desain Pengujian Peraturan Perundang-undangan Di Bawah Mahkamah Konstitusi, Jurnal Arena Hukum, 11 (2), 388-414. https://doi.org/10.21776/ub.arenahukum.2018.01002.9.

[14] Sirajuddin., Ramadhan, F. (2019). Dualisme Pengujian Yang Berujung Tirani Keterwakilan : Kajian atas Putusan Mahkamah Agung No. 65/P/HUM/2018 dan Putusan Mahkamah Konstitusi No. 30/PUU-XVI/2018. Jurrnal Hukum Kenegaraan, 2 (1), 1-20, 16-17.

[15] Suparto, S. (2020). Kontroversi Putusan Mahkamah Konstitusi Membatalkan Kewenangan Komisi Yudisial Melakukan Rekrutmen Terhadap Hakim. SASI, 26(2), 266-279. DOI: https://doi.org/10.47268/sasi.v26i2.252.

[16] Yunaldi, W. (2018). Judicial Review Satu Atap Peraturan Perundang-undangan Di Bawah Kewenangan Mahkamah Konstitusi. Pagaruyuang Law Journal, 1 (2), 198-219, https://jurnal.umsb.ac.id/index.php/pagaruyuang/article/view/565.

\section{Buku}

[17] Asshiddiqie, J., Safa'at, M. A. (2006). Teori Hans Kelsen Tentang Hukum, Jakarta: 
Sekretariat Jenderal dan Kepaniteraan Mahkamah Konstitusi RI.

[18] Asshiddiqie, J. (2010). Perihal Undang-Undang, Jakarta : Rajawali Pers. 